\title{
Pre-contamination of new gypsum wallboard with potentially harmful fungal species
}

\author{
Andersen, Birgitte; Dosen, Ina; Lewinska, Anna Malgorzata; Nielsen, Kristian Fog
}

Published in:

Indoor Air

Link to article, DOI:

10.1111/ina.12298

Publication date:

2017

Document Version

Peer reviewed version

Link back to DTU Orbit

Citation $(A P A)$ :

Andersen, B., Dosen, I., Lewinska, A. M., \& Nielsen, K. F. (2017). Pre-contamination of new gypsum wallboard with potentially harmful fungal species. Indoor Air, 27(1), 6-12. https://doi.org/10.1111/ina.12298

\section{General rights}

Copyright and moral rights for the publications made accessible in the public portal are retained by the authors and/or other copyright owners and it is a condition of accessing publications that users recognise and abide by the legal requirements associated with these rights.

- Users may download and print one copy of any publication from the public portal for the purpose of private study or research.

- You may not further distribute the material or use it for any profit-making activity or commercial gain

- You may freely distribute the URL identifying the publication in the public portal

If you believe that this document breaches copyright please contact us providing details, and we will remove access to the work immediately and investigate your claim. 
Received Date : 19-Oct-2015

Revised Date : 08-Jan-2016

Accepted Date : 04-Mar-2016

Article type : Original Article

Pre-contamination of new gypsum wallboard with potentially harmful fungal species

Birgitte Andersen*, Ina Dosen, Anna Malgorzata Lewinska, Kristian Fog Nielsen

Department of Systems Biology, Søltofts Plads, Technical University of Denmark, DK-2800 Kgs.

Lyngby, Denmark

*Corresponding author:

Phone: (+45) 4525 2726;

Fax: (+45) 4588 4922;

E-mail: ba@bio.dtu.dk (B.Andersen)

Running title: Pre-contamination of gypsum wallboard

This article has been accepted for publication and undergone full peer review but has not been through the copyediting, typesetting, pagination and proofreading process, which may lead to differences between this version and the Version of Record. Please cite this article as doi: 10.1111/ina.12298

This article is protected by copyright. All rights reserved. 
Keywords: Drywall, Chaetomium, Neosartorya, Stachybotrys, surface disinfection, recycled paper/cardboard

\section{Practical implications}

This study shows that wet gypsum wallboard, regardless of type or brand, is prone to fungal growth because fungi are already incorporated into the material during production. This study demonstrates the importance of securing buildings constructed with high amounts of gypsum wallboard against water-damage and high humidity. It also shows that industry has a major task ahead in ensuring that fungal spores are not built into their products and that a hazard analysis and critical control points approach, as used in the food industry, would seem to be a good strategy to ensure minimal fungal contamination of new building materials.

\section{ABSTRACT}

Gypsum wallboard is a popular building material, but is also very frequently overgrown by Stachybotrys chartarum after severe and/or undetected water damage. The purpose of this study was to determine if Stachybotrys and other fungi frequently isolated from wet gypsum wallboard are already present in the panels directly from the factory. Surface disinfected gypsum discs were wetted with sterile water, sealed and incubated for 70 days. The results showed that Neosartorya hiratsukae (三 Aspergillus hiratsukae) was the most dominant fungus on the gypsum wallboard followed by Chaetomium globosum and Stachybotrys chartarum. Our results suggest that these three fungal species are already embedded in the materials, presumably in the paper/carton layer surrounding the gypsum core, before the panels reach the retailers/building site.

This article is protected by copyright. All rights reserved. 


\section{Introduction}

Gypsum wallboard (drywall or plasterboard) is used extensively in both new builds and renovation projects throughout the world because it is cheap, easy to work with and fire resistant. It is, however, also prone to fungal growth if exposed to high humidity or water ingress. Growth of the filamentous fungus Stachybotrys chartarum is particularly associated with wet gypsum wallboard worldwide (Flannigan and Miller, 2011) and research has shown that in Danish water damaged buildings S. chartarum occurs on $25 \%$ of the gypsum wallboard samples, compared to only $4 \%$ in other samples examined (Andersen et al., 2011). Other filamentous fungal genera, such as Penicillium, Chaetomium and Ulocladium, have also been associated with wet gypsum wallboard (Gravesen et al., 1999; Flannigan and Miller, 2011), but these associations are less significant (Andersen et al., 2011).

Many filamentous indoor fungi can produce species specific bioactive metabolites during growth. Chaetomium globosum produces chaetoglobosins and Penicillium chrysogenum produces PR-toxin, roquefortines and penicillins, whereas S. chartarum is known for its production of macrocyclic trichothecenes and atranones (Nielsen et al., 1998; Samson et al., 2010). Some of these metabolites (roquefortine A, chaetoglobosin A and roridin E (a macrocyclic trichothecene) (Polizzi et al., 2009)) as well as fungal cell wall components ( $\beta$-glucans (Rand and Miller, 2011)) have been detected in indoor air and fungal growth in buildings is therefore problematic, as some of these compounds may have a negative impact on the health and well-being of the occupants (Nikulin et al., 1997; Mussalo-Rauhamaa et al., 2001; Carey et al., 2012; Rosenblum Lichtenstein et al., 2015). Especially S. chartarum is of concern, because it is also able to produce hemolytical proteins (Nayak et al., 2013) and macrocyclic trichothecenes that have previously been associated with of a number of animal and human health problems, e.g. leukopenia in horses, sheep and rabbits (Drobotko, 1944; Forgacs et al., 1958; Harrach, 1983; Jarvis et al., 1986) and pulmonary hemorrhage and hemosiderosis in infants in Cleveland (Jarvis et al., 1998; Etzel, 2007).

This article is protected by copyright. All rights reserved. 
S. chartarum can be found on mouldy cellulose rich materials, like hay, plant debris, enriched soil and paper (Ellis, 1971; Domsch et al., 2007), but is rarely detected in air (Baxter et al., 2005; Viegas et al., 2014), because the spores are borne in sticky slime heads (Samson et al., 2010). Detection of viable spores in air samples is usually only possible when large areas $\left(>\mathrm{m}^{2}\right)$ covered with Stachybotrys growth are disturbed and sampled close-up (Dill et al., 1997; Tiffany and Bader, 2000). C. globosum can be found in similar cellulose rich habitats as S. chartarum (Domsch et al. 2007) and is equally difficult to get airborne since its spores are borne in ascomata formed in cracks and cavities (von Arx et al., 1986). In nature, both species are thought to have beetles, ants and mites as dispersal vectors (von Arx et al., 1986; McGinnis, 2007).

Common belief has it that fungal growth in damp/wet buildings happens because fungal spores from outside drift indoors and randomly start growing on any available material. This may be true for genera, such as Aspergillus, Cladosporium and Penicillium, which are readily airborne and much more common in the environment (Samson et al., 2010). In the case of Chaetomium and Stachybotrys on gypsum wallboard, however, the lack of viable airborne spores in the outer environment and the overrepresentation of Stachybotrys on wet gypsum wallboard point to another source than outside air/environment as the origin of contamination. Price and Ahearn (1999) found Chaetomium and Stachybotrys in their untreated gypsum samples and noticed in a passing remark: "These species were presumably part of the inherent bioburden on the gypsum wallboard following manufacturing and storage." The purpose of this study is therefore to determine if Stachybotrys and other indoor fungi are already present in unused and undamaged gypsum wallboard.

This article is protected by copyright. All rights reserved. 


\section{Materials and Methods}

\subsection{Building materials, treatment and incubation}

Thirteen different panels of gypsum wallboard $(900 / 1200 \times 2400 \times 13 \mathrm{~mm})$ were bought in four different do it yourself (DIY) shops around Copenhagen over a period of six months. Two different brands and three different types of gypsum wallboard were used in the studies (see Table 1). Each panel was divided into four sections $(900 / 1200 \times 600 \mathrm{~mm})$ and three circular discs $(70 \mathrm{~mm}$ in diam.) were cut from each section (twelve discs in total per panel). Each set of 12 discs was surface disinfected for $30-45 \mathrm{sec}$. by submerging one disc at a time in $1000 \mathrm{ml}$ of $96 \%$ ethanol and gently rubbing both surfaces. Three additional sets of twelve discs from panel \# 9 were also surface disinfected in Rodalon (according to the directions for use), household bleach (according to the directions for use) or sterile water following the same procedure as for ethanol.

After surface disinfection, the discs were placed in a rack and allowed to air dry to constant weight, usually overnight, in a sterile laminar air flow (LAF) bench $\left(23-25^{\circ} \mathrm{C}\right.$ and $\left.30-35 \% \mathrm{RH}\right)$. Each disc was placed aseptically into an empty, sterile Petri dish (plastic, $90 \mathrm{~mm}$ in diam.) and weighed. Sterile water was added to the Petri dish to reach approximate $23 \%$ water content $(\mathrm{w} / \mathrm{w}$ of the constant weight) and weighed again. Each Petri dish was then sealed with parafilm and incubated at room temperature $\left(22-23^{\circ} \mathrm{C}\right)$ for 70 days. Discs of the first 9 planes were evaluated qualitatively for fungal growth every other week (presence or absence of each genus on a disc), through the lid without disturbing the disc, using a stereo microscope. Fungal colonies were identified to genus level based on their morphology. Discs of the last four planes were also evaluated on day 3 and 7 . After 70 days the Petri dishes were weighed again, opened and representative colonies isolated for species identification using morphology and metabolite profiling according to Andersen and Nissen (2000), Andersen et al. (2002; 2003), Samson et al. (2007), Samson et al. (2010) and Wang et al. (2016).

This article is protected by copyright. All rights reserved. 


\section{Results}

Analysis of the thirteen different planes of gypsum wallboard showed that there was fungal growth of one or more fungal species, on either the face, the reverse or on both, on all tested planes (Table 2). Plane 9 (moisture resistant, brand B) had the highest total fungal count (64 fungal counts on 12 discs), whilst plane 3 (fire resistant, brand B) had the lowest (21 fungal counts on 12 discs). The analyses also showed that there were no major differences between brands or between same types of plane purchased from different DIY outlets. During the 70 days each experiment lasted fungal growth and dissemination were followed and recorded using a stereo microscope. Only six genera, Neosartorya, Aspergillus, Chaetomium, Penicillium, Cladosporium and Stachybotrys, reoccurred on three or more of the thirteen panels (Table 2). Alternaria, Botrytis, Phoma and Ulocladium were found on only one panel and one or two discs, while Harzia, Paecilomyces and Pochonia, were found only once.

\subsection{Fungal identification}

At day 70 the seals of the Petri dishes were broken and representative colonies were isolated and identified to species. The most abundant fungal species found on gypsum wallboard was Neosartorya hiratsukae. This fungus was found on all thirteen panels (100 \%) and on most discs; both face and reverse. It appeared first on the reverse of the discs, but within days it was also visible on the face. The fungus had covered the whole disc with small (100-230 $\mu \mathrm{m}$ in diam.) white ascomata (cleistothecia) (Fig. 1A/D) in 3-7 days after first appearance. Only on panel 5 was $N$. hiratsukae more abundant on the face than on the reverse (Table 2). The most abundant Aspergillus turned out to be $A$. hiratsukae, which is the asexual state of $N$. hiratsukae (i.e. the same organism as $N$. hiratsukae), and was found around the edge of the discs and constituted most of the recorded "Aspergillus" in Table 2. C. globosum was the second most abundant species, found on eleven panels

This article is protected by copyright. All rights reserved. 
( $85 \%)$ and was equally common on both face and reverse. It took ca. 14 days after onset for the fungus to cover the whole surface of the disc with large (300-500 $\mu \mathrm{m}$ in diam.) dark ascomata (perithecia) with green curly hair (Fig. 1B/E). Both P. chrysogenum and Cladosporium cladosporioides showed the same pattern by occurring mostly on the face of nine (69 \%) and eight (62 \%) panels, respectively, and only as discrete, slow growing colonies that stopped expanding after 14-21 days (Fig. 1B). S. chartarum (both chemo types) was found on seven (54 \%) of the thirteen panels and would cover the whole surface of the disc within 7 days after onset with black clusters of slime heads (Fig. 1C/F). Alternaria infectoria, Aspergillus versicolor and Cladosporium sphaerospermum were found on only one panel and on one or two discs, while Aspergillus fumigatus, Chaetomium elatum, Penicillium polonicum were found only once.

\subsection{Surface disinfection}

After the emergence of $N$. hiratsukae ascomata on the first 5 panels, it was speculated whether the ethanol was triggering the growth of this fungus or if it could be present in the ethanol. Therefore two other surface disinfectants, household bleach and Rodalon, and autoclaved water were also used on subsamples of panel 9. Analysis of the three subsamples showed similar results compared to ethanol disinfection (Table 3). With water and bleach the ascomata of $N$. hiratsukae appeared just as rapidly (14 days) as they did with ethanol, whereas the Rodalon treatment delayed the ascomata production by ca. 7 days. The subsample washed in autoclaved water did not show any additional fungal growth and neither bleach nor Rodalon hampered the growth of $S$. chartarum. Table 3 also shows that the water content of the discs decreased slightly from $22.5 \%$ to $20.8 \%$ on average during the 70 day long incubation period despite several layers of parafilm around the edge of the Petri dishes.

This article is protected by copyright. All rights reserved. 


\subsection{Onset of fungal growth}

The last four panels (panels 10-13) were also examined on day 3 and day 7 to see how quickly the fungi could germinate, grow and sporulate. Figure 2 shows the onset of sporulation for each genus and the end time where no new fungal colonies appear. The first undifferentiated hyphal growth was evident on day 3 (graph not shown) and conidial heads of $A$. hiratsukae were visible after only 7 days of incubation, whereas $N$. hiratsukae ascomata started to appear after 14 days. Also $C$. cladosporioides and P. chrysogenum were visible after 14 days with conidiophores and the first chains of conidia. The first slime heads of S. chartarum were visible after 21 days, while $C$. globosum ascomata were visible after 28 days (panels 6-9, result not shown). No new colonies appeared after 42-45 days.

\section{Discussion}

The results of this study show that gypsum wallboard is already contaminated with fungal spores before the panels reach their end-users, since the same fungal species, Neosartorya hiratsukae (三 Aspergillus hiratsukae), Chaetomium globosum and Stachybotrys chartarum, were found repeatedly in the paper/cardboard of all surface disinfected samples irrespectively of type, brand or outlet.

N. hiratsukae, which is an uncommon fungus in the environment, has to our knowledge never been reported on gypsum wallboard before. It has previously been isolated from soil, fruit juice and indoor air (Samson et al., 2007). N. hiratsukae is also reported to be pathogenic to humans (Guarro et al., 2002) and to produce avenaciolide (Samson et al., 2007). One reason for occupants and surveyors not to realize growth of this fungus could be that the small white ascomata are evenly distributed across the white paper surface of the gypsum wallboard and therefore not readily visible to the naked eye (Fig. 1A) and difficult to see without a slanted light source on the stereo microscope. The pale green anamorphic state of the fungus, A. hiratsukae, is produced only

This article is protected by copyright. All rights reserved. 
sparingly on gypsum wallboard. During the 70 day incubation period it was noted how the ascomata slowly disintegrated and released vast numbers of ascospores. This suggests that $N$. hiratsukae spores (both live and dead) and micro-particles from the ascomata can easily become airborne and constitute a health risk in buildings with water damaged gypsum wallboard without the knowledge of the occupants.

A limited number of research studies have been published on the occurrence of $C$. globosum in water damaged buildings and even fewer have reported C. globosum on paper and gypsum wallboard (Price and Ahearn, 1999; Jerusik, 2010; Flannigan and Miller, 2011). One reason for not detecting C. globosum, even though it is very conspicuous on gypsum wallboard when mature (Fig. 1B), may be its long lag phase on both gypsum and laboratory media. Furthermore, samples from water damaged buildings often contain other fungi (e.g. Penicillium spp.) that grow much faster on laboratory media and thereby obscure any growth of $C$. globosum.

The association between S. chartarum and gypsum wallboard, on the other hand, is well documented and it was therefore expected that S. chartarum would be the dominant fungus. Still, more than $50 \%$ of our panels were contaminated with S. chartarum, which is more than some studies report (Gravesen et al., 1999; Andersen et al., 2011), but less than the 60-77 \% Flannigan and Miller (2011) found in their study. If our results are representative for a panel (1 out of 12 discs is contaminated with one viable S. chartarum spore) it would suggest that a whole panel would be contaminated with $40-60$ viable spores depending on the size of the panel (ca. 20 spores $/ \mathrm{m}^{2}$ ). This corresponds well to our field observations in buildings with severe water-damage. There we have seen simultaneous outgrowth of numerous discrete Stachybotrys colonies on the same gypsum panel indicating that Stachybotrys spores are distributed throughout the material. On our most contaminated sample, panel 5, where 10 discs were contaminated, the same estimation would give approximately 200 viable $S$. chartarum spores per $\mathrm{m}^{2}$. This combined with the rapid growth rate on

This article is protected by copyright. All rights reserved. 
gypsum wallboard (covering a disc in less than a week) might explain why S. chartarum can dominate a water damaged building so quickly.

Most gypsum wallboard manufacturers advertise that they use recycled materials in their production. Recycled paper/cardboard is often collected in big bails at the recycling centre and stored under less than optimal conditions (Jerusik, 2010) where bails are exposed to rain, soil and insects, which results in high microbial loads (Betz and Cerny, 1999). N. hiratsukae, as well as C. globosum and S. chartarum, can survive at temperatures around $40^{\circ} \mathrm{C}$ (Samson et al., 2007; Domsch et al., 2007) and even if a small percentage of the fungal spores survive pulping and drying, there could be invisible fungal growth on the gypsum wallboard after as little as 7 days after major waterdamage. However, since it is not known where in the process the different fungi enter or what their contamination and survival rates are, further research into the specific production methods of the raw materials is needed. One approach to safer gypsum wallboard is for the manufacturers to use hazard analysis and critical control points (HACCP), which is a system used by the food industry for decades to ensure food safety, but other types of industry are increasingly using HACCP as a competitive parameter.

Ongoing chemical analyses of the discs at our department will show which fungal metabolites (e.g. avenaciolide, chaetoglobosins, atranones and satratoxins) these inbuilt fungal contaminants are able to produce during their growth on the gypsum wallboards and if it is consistent with previous findings on Stachybotrys spp. (Nielsen et al., 1998). Also a rapid detection method using DNA sequencing directly on the paper/cardboard surface is being developed at our department.

This article is protected by copyright. All rights reserved. 


\section{Conclusions}

The results of this work show that gypsum wallboard is contaminated with Neosartorya,

Chaetomium and Stachybotrys and suggest that the spores of these fungi are embedded in the paper/cardboard surrounding the gypsum core. Even though the manufacturers do not market their gypsum wallboard as "sterile" or "fungal free", most consumers trust that there are no potentially harmful fungi in their building materials. Since growth of these fungi can result in large quantities of micro-particles and bioactive compounds, which may be released into the indoor air after water damage, there is a need for manufacturers to undertake a stricter quality control of their raw materials and finished products. However, even the best efforts of the manufacturers would be rendered futile if proper/correct shipping, handling and storage are not equally strictly controlled.

During storage, construction and occupancy, gypsum wallboard must be kept dry, clean and undamaged in order to provide safe and healthy buildings.

\section{Acknowledgements}

The authors would like to thank the VILLUM Foundation for financial support for this work, Peter Meinke, DTU Systems biology, for cutting all the gypsum wallboard discs and Jens C. Frisvad, DTU Systems biology, for confirming the identity of Neosartorya hiratsukae/Aspergillus hiratsukae.

\section{References}

Andersen, B. and Nissen, A.T. (2000) Evaluation of media for detection of Stachybotrys and Chaetomium species. International Biodeterioration and Biodegradation, 46, 111-116.

Andersen, B., Frisvad, J.C., Søndergaard, I., Rasmussen, I.S. and Larsen, L.S. (2011) Associations between fungal species and water damaged building materials. Applied and Environmental Microbiology, 77, 4180-4188.

This article is protected by copyright. All rights reserved. 
Andersen, B., Nielsen, K.F. and Jarvis, B.B. (2002) Characterization of Stachybotrys from waterdamaged buildings based on morphology, growth and metabolite production, Mycologia 94, 392-403.

Andersen, B., Nielsen, K.F., Thrane, U., Szaro, T., Taylor, J.W. and Jarvis, B.B. (2003) Molecular and phenotypic descriptions of Stachybotrys chlorohalonata sp. nov. and two chemotypes of Stachybotrys chartarum found in water-damaged buildings, Mycologia, 95, 1227-1238.

Baxter, D.M., Perkins, J.L., McGhee, C.R. and Seltzer, J.M. (2005) A Regional Comparison of Mold Spore Concentrations Outdoors and Inside "Clean" and "Mold Contaminated" Southern California Buildings, Journal of Occupational and Environmental Hygiene 2, 8-18.

Betz, M and Cerny, G. (1999) Mikrobiologische Untersuchungen an Hygienpapieren mit und ohne Zusatz von Altpapier Papier, 53, 376-383.

Carey, S.A., Plopper, C.G., Hyde, D.M., Islam, Z., Pestka, J.J. and Harkema, J.R. (2012) Satratoxin-G from black mold Stachybotrys chartarum induces rhinitis and apoptosis of olfactory sensory neurons in the nasal airways of rhesus monkeys, Toxicologic Pathology, 40, 887-898.

Dill, I., Trautmann C. and Szewzyk, R. (1997) Massenentwicklung von Stachybotrys chartarum auf kompostierbaren Pflanztöpften aus Altpapier, Mycoses, 40, 110-114.

Domsch, K.H., Gams, W. and Anderson, T.H. (2007) Compendium of soil fungi, Germany, Eching, IHW-Verlag, Ed. 2 pp 4-672.

Drobotko, V.G. (1944) Stachybotryotoxicosis. A new disease of horses and humans, American Review of Soviet Medicine, Vol 2, 238-242.

Ellis, M.B. (1971) Dematiaceous Hyphomycetes, Kew, Surrey, UK, Commonwealth Mycological Institute, pp 5-608.

This article is protected by copyright. All rights reserved. 
Etzel, R.A. (2007) Indoor and outdoor air pollution: Tobacco smoke, moulds and diseases in infants and children, Int. J. Hyg. Environ. Health, 210, 611-616.

Flannigan, B. and Miller, J.D. (2011) Microbial growth in indoor environments. In: B. Flannigan, R.A. Samson and J. David Miller (eds) Microorganisms in Home and Indoor Work Environments. Diversity, health impacts, investigation and control, Boca Raton, FL, CRC Press, Ed. 2, pp 57107.

Forgacs, J., Carll, W. T., Herring, A. S. and Hinshaw, W.R. (1958) Toxicity of Stachybotrys atra for animals, Trans New York Acad Sci, 20, 787-808.

Gravesen, S., Nielsen, P.A., Iversen, R. and Nielsen, K.F. (1999) Microfungal contamination of damp buildings - examples of risk constructions and risk materials, Environ Health Perspect, $107,505-508$.

Guarro, J., Kallas, E.G., Godoy, P., Karenina, A., Gené, J., Stchigel, A. and Colombo, A.L. (2002) Cerebral aspergillosis caused by Neosartorya hiratsukae, Brazil, Emerging Infectious Diseases, 8, 989-991.

Harrach, B., Bata, A., Bajmocy, E. and Benko, M. (1983) Isolation of satratoxins from the bedding straw of a sheep flock with fatal stachybotryotoxicosis, Applied and Environmental Microbiology, 45, 1419-1422.

Jarvis, B.B., Lee, Y.W., Comezoglu, S.N. and Yatawara, C.S. (1986) Trichothecenes produced by Stachybotrys-atra from Eastern-Europe, Applied and Environmental Microbiology, 51, 915918.

Jarvis, B.B., Sorenson, W.G., Hintikka, E.L., Nikulin, M., Zhou, Y.H., Jiang, J., Wang, S.G., Hinkley, S., Etzel, R.A. and Dearborn, D. (1998) Study of toxin production by isolates of Stachybotrys

This article is protected by copyright. All rights reserved. 
chartarum and Memnoniella echinata isolated during a study of pulmonary hemosiderosis in infants. Applied And Environmental Microbiology, 64, 3620-3625.

Jerusik, R.J. (2010) Fungi and paper manufacture, Fungal Biology Reviews, 24, 68-72.

McGinnis, M.R. (2007) Indoor mould development and dispersal, Medical Mycology, 45, 1-9.

Mussalo-Rauhamaa, H., Nikulin, M., Koukila-Kahkola, P., Hintikka, E.L., Malmberg, M. and Haahtela, T. (2010) Health Effects of Residents Exposed to Stachybotrys in Water-damaged Houses in Finland, Indoor and Built Environment, 19, 476-485

Nayak, A.P., Green, B.J. and Beezhold, D.H. (2013) Fungal hemolysins, Medical Mycology, 51, 1-16.

Nielsen, K.F., Hansen, M.Ø., Larsen, T.O. and Thrane, U. (1998) Production of trichothecene mycotoxins on water damaged gypsum boards in Danish buildings, International Biodeterioration \& Biodegradation, 42, 1-7.

Nikulin, N., Reijula, K., Jarvis, B.B. and Hintikka E.-L. (1997) Experimental lung mycotoxicosis induced by Stachybotrys atra, Int. J. Experim. Pathol. 77:213-218.

Price, D.L. and Ahearn, D.G. (1999) Sanitation of Wallboard Colonized with Stachybotrys chartarum, Current Microbiology, 39, 21-26.

Polizzi, V., Delmulle, B., Adams, A., Moretti, A., Susca, A., Picco, A.M., Rosseel, Y., Kindt, R., Van Bocxlaer, J., De Kimpe, N., Van Peteghem, C., De Saeger, S. (2009) JEM spotlight: Fungi mycotoxins and microbial volatile organic compounds in mouldy interiors from waterdamaged buildings, Journal of Environmental Monitoring, 11, 1849-1858.

Rand, T.G. and Miller, J.D. (2011) Analysis for toxins and inflammatory compounds. In: B. Flannigan, R.A. Samson and J. David Miller (eds) Microorganisms in Home and Indoor Work Environments. Diversity, health impacts, investigation and control, Boca Raton, FL, CRC Press, Ed. 2, pp 291-306.

This article is protected by copyright. All rights reserved. 
Rosenblum Lichtenstein, J.H., Hsu, Y.-H., Gavin, I.M., Donaghey, T.C., Molina, R.M., Thompson, K.J., Chi, C.-L., Gillis, B.S. and Brain, J.D. (2015) Environmental mold and mycotoxin exposures elicit specific cytokine and chemokine responses, PLOS ONE, 10, e0126926.

Samson, R.A., Hong, S., Peterson, S.W., Frisvad, J.C. and Varga, J. (2007) Polyphasic taxonomy of Aspergillus section Fumigati and its teleomorph Neosartorya, Stud. Mycol., 59, 147-207.

Samson, R.A., Houbraken, J., Thrane, U., Frisvad, J.C. and Andersen, B. (2010) Food and Indoor Fungi. Utrecht, the Netherlands, CBS-KNAW-Fungal Biodiversity Centre, pp. 1-398.

Tiffany, J.A. and Bader, H.A. (2000) Detection of Stachybotrys chartarum: The effectiveness of culturable-air sampling and other methods, Journal of Environmental Health, 62, 9-11.

Viegas, S., Sabino, R., Viegas, C., Faria, T., Quintal Gomes, A. and Seco, A. (2014) Fungal contamination in two Portuguese wastewater treatment plants. Journal of Toxicology and Environmental Health, 77, 90-102.

von Arx, J.A., Guarro, J. and Figueras, M.J. (1986) The Ascomycete Genus Chaetomium, Nova Hedwigia, Heft 84, 1-162.

Wang, X.W., Lombard, L., Groenewald, J.Z., Videira, S.I.R., Samson, R.A., Liu, X.Z. and Crous P.W. (2016) Phylogenetic reassessment of the Chaetomium globosum species complex, Persoonia, $36,83-133$.

This article is protected by copyright. All rights reserved. 


\section{Figure legends}

Fig. 1. Gypsum discs (face up) with fungal growth after 70 days. A/D: Neosartorya hiratsukae (panel 3); B/E: Chaetomium globosum (panel 1) with Penicillium chrysogenum encircled; C/F: Stachybotrys chartarum (panel 3).

Fig. 2. Time (days) until first appearance of fungal growth/sporulation on discs (both face and reverse) from panels $10-13(n=96)$.

Table 1. Type and origin (anonymised) of the gypsum wallboard panels used in this study.

\begin{tabular}{|c|c|c|c|c|}
\hline Panel \# & Type of wallboard & Brand & Outlet & Purchase date \\
\hline 1 & Fire resistant & $A$ & DTU* & $14-01-2015$ \\
\hline 2 & Fire resistant & $A$ & DIY-1 & 20-01-2015 \\
\hline 3 & Fire resistant & B & DIY-2 & 17-03-2015 \\
\hline 4 & Moisture resistant & B & DIY-2 & 17-03-2015 \\
\hline 5 & Fire resistant-spacer & $A$ & DIY-1 & 23-03-2015 \\
\hline 6 & Fire resistant & $A$ & DIY-3 & $30-04-2015$ \\
\hline 7 & Moisture resistant & $A$ & DIY-3 & $30-04-2015$ \\
\hline 8 & Fire resistant & B & DIY-4 & $30-04-2015$ \\
\hline 9 & Moisture resistant & B & DIY-4 & $30-04-2015$ \\
\hline 10 & Fire resistant & $A$ & DIY-1 & $13-07-2015$ \\
\hline 11 & Regular & $A$ & DIY-1 & $13-07-2015$ \\
\hline 12 & Fire resistant-spacer & $A$ & DIY-1 & $13-07-2015$ \\
\hline 13 & Fire resistant & B & DIY-2 & $13-07-2015$ \\
\hline
\end{tabular}

* Clean, unused surplus panel from a building site at the Technical University of Denmark.

This article is protected by copyright. All rights reserved. 
Table 2. Number of discs with fungal growth on face (F) and reverse (R) from 13 different gypsum wallboard panels. Twelve discs from each panel were surface disinfected with ethanol, wetted with sterile water and incubated for 70 days.

\begin{tabular}{ccccccccccccccc}
\hline & \% Water & \multicolumn{1}{l}{ Neosartorya } & Aspergillus & \multicolumn{2}{c}{ Chaetomium } & Cladosporium & Penicillium & \multicolumn{2}{c}{ Stachybotrys } \\
\hline Panel \# & day 1 & F & R & F & R & F & R & F & R & F & R & F & R \\
\hline 1 & 21.6 & 4 & 10 & - & 1 & 7 & 8 & 3 & - & 5 & 1 & 7 & 7 \\
2 & 21.3 & 8 & 12 & - & - & 5 & 3 & 2 & - & 3 & 1 & 1 & 1 \\
3 & 27.0 & 2 & 9 & - & - & - & - & - & - & 1 & 1 & 4 & 4 \\
4 & 21.8 & 8 & 8 & 7 & 5 & 4 & 4 & 3 & 1 & 6 & 4 & 1 & 2 \\
5 & 24.2 & 11 & 1 & 3 & 1 & 2 & 3 & 2 & - & 2 & - & 10 & 11 \\
6 & 22.8 & 12 & 12 & 2 & - & 2 & 1 & 1 & - & - & - & - & - \\
7 & 23.2 & 12 & 12 & - & 1 & 2 & 1 & - & - & - & 1 & - & - \\
8 & 23.6 & 3 & 7 & 1 & - & 1 & 1 & 9 & - & 1 & - & - & - \\
9 & 23.0 & 12 & 12 & 12 & 12 & 3 & 4 & - & - & 8 & - & 1 & - \\
10 & 23.2 & 12 & 11 & 12 & - & 2 & 1 & - & - & - & - & 1 & 1 \\
11 & 22.5 & 12 & 12 & 4 & - & - & - & 4 & - & - & - & - & - \\
12 & 22.5 & 12 & 12 & 4 & 2 & 1 & - & - & - & - & - & - & - \\
13 & 23.0 & 6 & 12 & 1 & 2 & 1 & 2 & 8 & - & 3 & 1 & - & - \\
\hline
\end{tabular}

This article is protected by copyright. All rights reserved. 
Table 3. Number of discs with fungal growth on face $(F)$ and reverse $(R)$ from panel 9 after treatment with 4 different surface disinfectants. Twelve discs for each treatment were surface disinfected, wetted with sterile water and incubated for 70 days.

\begin{tabular}{|c|c|c|c|c|c|c|c|c|c|c|c|c|c|c|}
\hline \multirow{2}{*}{$\begin{array}{l}\text { Surface } \\
\text { disinfectan } \\
t\end{array}$} & \multicolumn{2}{|c|}{$\begin{array}{c}\text { \% Water } \\
(w / w)\end{array}$} & \multicolumn{2}{|c|}{$\begin{array}{c}\text { Neosartory } \\
a\end{array}$} & \multicolumn{2}{|c|}{$\begin{array}{c}\text { Aspergillu } \\
s\end{array}$} & \multicolumn{2}{|c|}{$\begin{array}{c}\text { Chaetomiu } \\
m\end{array}$} & \multicolumn{2}{|c|}{$\begin{array}{c}\text { Cladosporiu } \\
m\end{array}$} & \multicolumn{2}{|c|}{$\begin{array}{c}\text { Penicilliu } \\
m\end{array}$} & \multicolumn{2}{|c|}{$\begin{array}{c}\text { Stachybotry } \\
s\end{array}$} \\
\hline & day 1 & day 70 & $F$ & $R$ & $F$ & $\mathrm{R}$ & $F$ & $\mathrm{R}$ & $F$ & $\mathrm{R}$ & $\mathrm{F}$ & $R$ & $F$ & $\mathrm{R}$ \\
\hline Ethanol & 23.0 & 21.6 & 12 & 12 & 12 & 12 & 3 & 4 & - & - & 8 & - & 1 & - \\
\hline Water & 21.6 & 19.9 & 12 & 12 & 12 & 12 & 3 & 5 & 2 & - & 10 & 9 & - & - \\
\hline Bleach & 22.3 & 21.0 & 12 & 12 & 12 & 12 & 3 & 2 & - & - & 6 & - & 2 & 2 \\
\hline Rodalon & 23.1 & 20.7 & 12 & 12 & 12 & - & 2 & - & - & - & 7 & - & - & 1 \\
\hline
\end{tabular}

This article is protected by copyright. All rights reserved. 

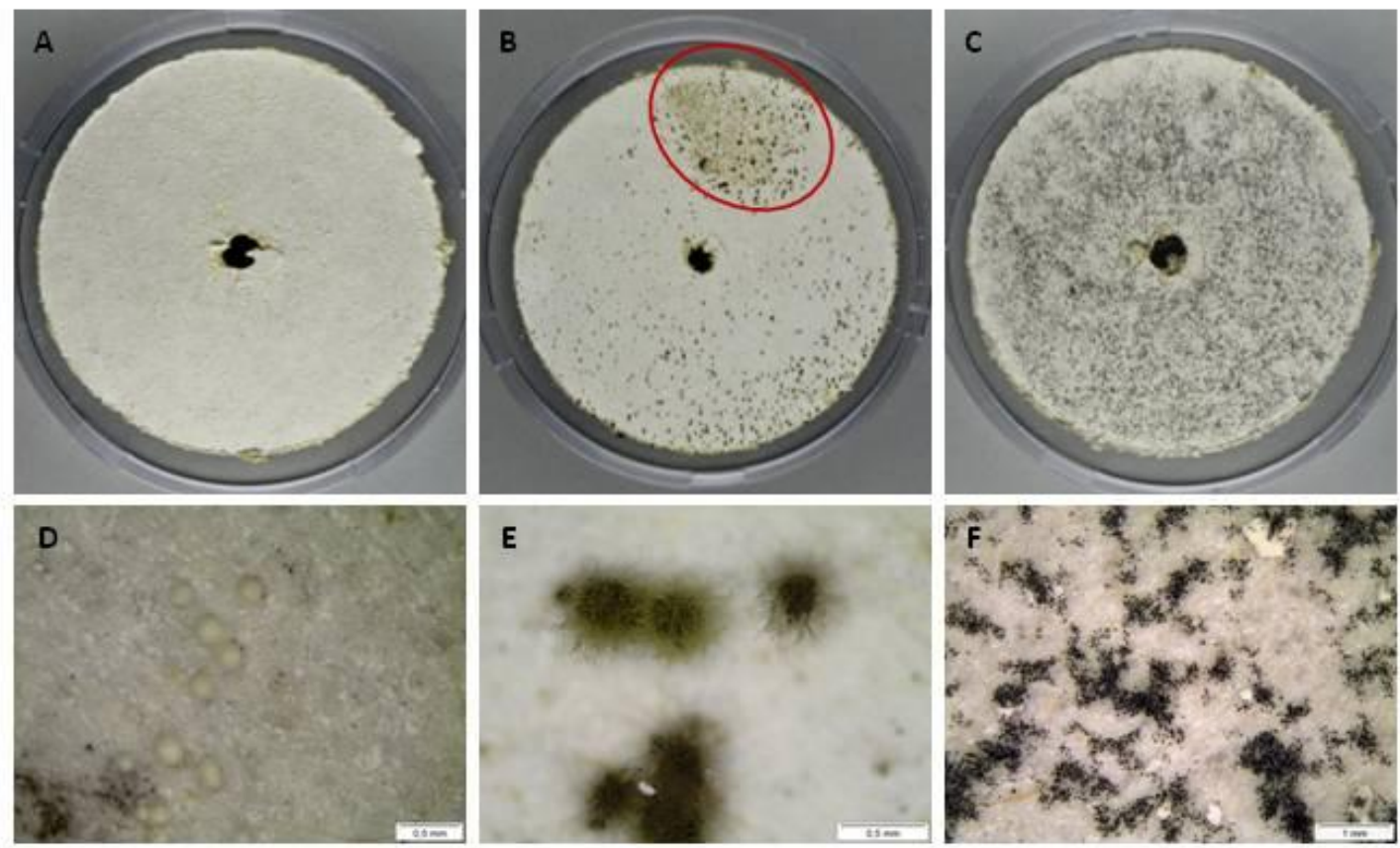

Fig. 1. Gypsum discs (face up) with fungal growth after 70 days. A/D: Neosartorya hiratsukae (panel 3); B/E: Chaetomium globosum (panel 1) with Penicillium chrysogenum encircled; C/F: Stachybotrys chartarum (panel 3).

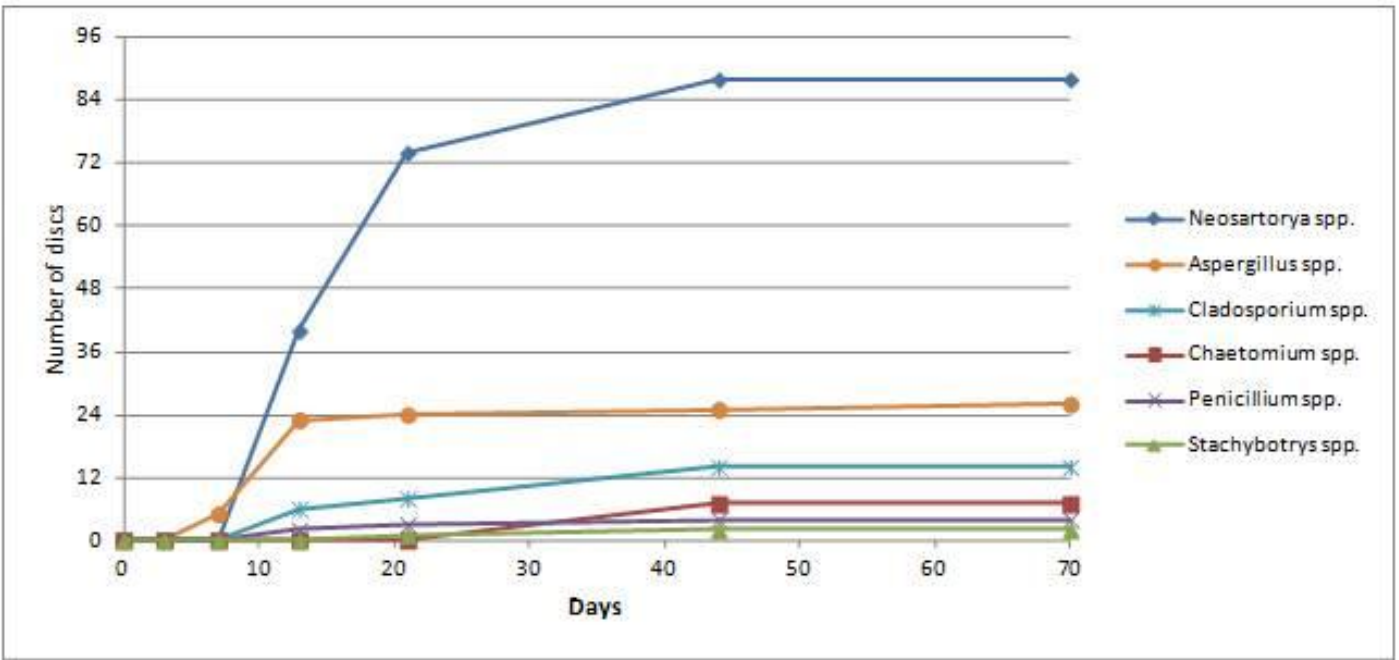

Fig. 2. Time (days) until first appearance of fungal growth/sporulation on discs (both face and reverse) from panels $10-13(n=96)$.

This article is protected by copyright. All rights reserved. 